\title{
Upper Lobe of the Right Lung
}

National Cancer Institute

\section{Source}

National Cancer Institute. Upper Lobe of the Right Lung. NCI Thesaurus. Code C33023.

The lobe of the right lung, situated above the horizontal fissure, which includes the apex. 